\title{
Online Argumentation Implementation in the Development of Critical Thinking Disposition
}

\author{
Pınar Fettahlıŏlu ${ }^{1}$, Devkan Kaleci ${ }^{2}$ \\ ${ }^{1}$ Cukurova University, Faculty of Education, Science Education Department, Turkey \\ ${ }^{2}$ Department of Computer and Instructional Technology Education, Education Faculty, Inonu University, Malatya, \\ Turkey \\ Correspondence: Pınar Fettahlıoğlu, Cukurova University, Faculty of Education, Science Education Department, \\ Turkey.
}

Received: January 10, 2018

doi:10.11114/jets.v6i3.2904

\author{
Accepted: February 12, $2018 \quad$ Online Published: February 22, 2018
}

URL: https://doi.org/10.11114/jets.v6i3.2904

\begin{abstract}
The purpose of this study is to investigate the effects of teaching technologies and material development course taught through Moodle based online argumentation implementation on critical thinking disposition of third year science teacher candidates. The study was carried out with a total of 43 students consisting of an experimental group of 22 and a control group of 21 students studying at the Department of Science Education at a State University Faculty of Education in the fall term of 2014-15 academic years. Sequential explanatory design was used as a mixed method strategy in this research. A quasi-experimental pre-test/post-test non-equivalent control group design was used in the quantitative part of the study. A case study research design was used in the qualitative part of the study. California Critical Thinking Disposition Inventory was used as data collection tool. In addition, an open-ended interview questions form was used to define opinions of science teacher candidates about the method applied in the course. Independent samples t-test and paired samples t-test were used in the analysis of quantitative data. Descriptive analysis was used to analyse qualitative data. At the end of the research, while a statistically significant difference in critical thinking dispositions of teacher candidates was observed in favour of post-test results of the experimental group, no statistically significant difference was observed in the control group. When the opinions of teacher candidates on the subject were investigated, it was found that the teacher candidates strongly supported the elimination of internet connection problems to improve the course.
\end{abstract}

Keywords: argumentation, teacher training, environmental education, self-efficacy

\section{Introduction}

The changing and improving life conditions with the developments in the information age have brought forth the demand in all fields of life and especially in the business world for people who constantly improve themselves and solve the problems they encounter. However, exact solutions for problems are reached at in the light of accurate and valid information. When this fact is considered it can be said that the embracement of relevant and irrelevant, accurate and inaccurate information by the society without questioning obstructs the emergence of this demanded profile. The ever increasing awareness about lack of thinking has also increased the interest in thinking skills. One of these thinking skills is critical thinking. Critical thinking, which can be traced back to Socrates, can actually be expressed as the most improved and advanced form of thinking. Critical thinking means thinking objectively, thoroughly and without any obsessions. In this regard, qualified and accurate can be discerned from unqualified and inaccurate through critical thinking (İpşiroğlu, 2002; Tümkaya \& Aybek, 2008). Paul (1992), well known for his work on critical thinking, defines critical thinking as thinking on the process of thinking while doing it to improve one's own thinking and indicates there are two quite important things in his definition. He explains them as follows (FCT [Foundation for Critical Thinking], 1992)

- Critical thinking is not just thinking; it is also thinking about the things that are effective to improve oneself.

- Improving oneself is related to a person's skills about the standards he would use while thinking.

Schafersman (1991) emphasizes that critical thinking is a more professional, improved, qualified and effective thinking 
skill and states that it cannot be taught by peers or families. Smith (2003) and Bailin (2002) also stress those critical thinking needs to be in the curricula of all levels of education. So, according to Schafersman (1991) the acquisition of critical thinking can be done through formal education. In this regard, the schools of our age project teaching of critical thinking in lessons and critical thinking in administrative decision making for the problem of how students typically think. Critical thinking skills were included in the curriculum of science courses with the modification in formal education in 2013 and activities have been updated accordingly. However, it is not enough to improve critical thinking skills by having critical thinking learning outcomes only in the curriculum. In addition to this teacher also need to have these skills (Thomas, 2009). A curriculum can be renewed and new learning outcomes can be designated. However, the implementation of the curriculum effectively by willing and qualified teachers is another aspect that needs to be considered. In other words, curricula, method and techniques and, teaching materials and tools cannot have a desired affect without the live figure of a teacher (Sözer, 1991). Students are affected by the teacher's opinions, attitudes and perspective on the course and these usually affect students' success and attitudes towards the course accordingly (Bruner, 1966). Universities have a specific responsibility to provide alternative thinking and so it is important especially in teacher training departments to create extracurricular learning environments in the education process where in class teaching method and techniques that provide teacher candidates with opportunities to think differently and alternatively are applied. With these opportunities there would be a democratic, liberal, innovative and equal understanding and as a result the critical thinking of students would be actualized. In this regard the role of universities in training critical thinking individuals is really great. Therefore, it is important to study the factors that affect teacher candidates' critical thinking skills, to work to improve these skills using the results obtained and to plan courses supporting the development of these skills at the faculties of education.

When the relevant literature is examined it is observed that an argumentation implementation is one of the subjects recently emphasized among the method and techniques supporting critical thinking development. Argumentation implementations were integrated into education system with the Toulmin model of argument and later various argument models have been developed (Kelly \& Takao, 2002; Lawson, 2003; Sandoval, 2003; Toulmin, 1958; Zohar \& Nemet, 2002). Because of the nature of argumentation implementations, no matter which scheme is applied, it is one of the leading applications in the development of students' higher order skills such as questioning, critical thinking, reasoning and problem solving skills (Fettahlıoğlu, 2012, Jimenez-Alexandre, 2008). In argumentation implementations, at first, students present their arguments on a problem and then start searching data to support their argument. The purpose in this process is to show the opponents how strong their arguments are. They both find out new information about the subject while discovering and interpreting various data to support their argument and have a chance to take a different approach to the subject matter by listening to counter arguments. This process also involves students convincing their peers to agree on their arguments with the supportive data they have. Thus, both group cooperation and research and investigation skills are effectively employed in this process (Jimenez Alexandre \& Puig, 2011).

On the other hand, one of the recently accentuated applications is Moodle based learning environments. The widespread use of internet and personal computers has pawed the way for such technologies to be used in education as in many other fields. Thus, learning management systems which have many components in education activities have become widespread and now are a basic part of education. Learning Management Systems (LMS) is a general name for educational categories including implementation such as virtual learning environments, course management systems, and collaborative learning environments (Kaleci, 2013). One of the biggest advantages of learning management systems is that they have a modular structure that can support both distance learning and traditional education. In addition, LMSs offer various developable tools like video conference, exam, chat room, sharing and uploading course materials, creating new courses, instructional task, instructor feedbacks, video player, discussion forum, assessment management, virtual class, blog page, etc. (Kaleci \& Kapıdere, 2014; Schoonenboom, 2014). Moodle (Modular Object Oriented Dynamic Learning Environment) is a learning platform designed to provide educators, administrators and learners with a single robust, secure and integrated system to create personalized learning environments (Moodle, 2017b). Moodle is a flexible, reliable, and the most preferred completely free learning management system that meets almost all the needs of individuals or organizations providing distance learning. The teacher or the learner does not need to write even a single line of codes to use it. Currently, Moodle is available in 130 languages with registered installations used by more than 71.892 registered sites, 9.997.285 courses, and 88.090.368 users in 233 countries (Moodle, 2017a). Especially with its open source software coding and modular structure it improves continuously and grows rapidly with new modules and extensions. When compared to other learning management system, apart from being completely free of charge, Moodle is observed to be more effective in use and in meeting students' needs (Rafi, Samsudin, \& Hanafi, 2015). Moodle is the most preferred learning management system and so it has started to be preferred in argumentation applications along with all other fields of education in the last few years. (Choi, Hand, \& Norton-Meier, 2014; Piwek \& Keynes, 2013; Ryan-Atkin, 2015; Zengin, Keçeci, \&Kırılmazkaya, 2012). However, when the relevant literature is examined, no study has been found that applies Moodle based argumentation implementation to support critical 
thinking skills of science teacher candidates. Therefore, the purpose of this study is to investigate the effects of teaching technologies and material development course taught with moodle based online argumentation implementation on the critical thinking disposition of third year science teacher candidates. Within the context of this purpose the following questions are addressed.

Within the context of the study following questions are addressed.

- Critical thinking disposition of experimental and control groups teacher candidates

o Is there a significant difference between pre-test averages?

o Is there a significant difference between post-test averages?

- Is there a statistically significant difference between pre-test and post-test averages of experimental group teacher candidates' critical thinking disposition?

- Is there a statistically significant difference between pre-test and post-test averages of control group teacher candidates' critical thinking disposition? What are opinions of the experimental group teacher candidates about the method applied?

\section{Method}

This study was conducted sequential explanatory design as a mixed method strategy in this research. In sequential explanatory design, firstly, the quantitative data is collected. Then, qualitative data that would help descend to particulars and explain quantitative data is collected. The main emphasis of the study is on quantitative results, qualitative results are secondary (McMillan \& Schumacher, 2006). A quasi-experimental pre-test/post-test non-equivalent control group design was used in the quantitative part of the study. A case study research design was used in the qualitative part of the study. Within this framework, primarily, the planned method was applied and quantitative data about the application was collected and after that an open-ended interview questions form was used to define teacher candidates' opinions about the method applied in the course. Thus, mainly quantitative and secondarily qualitative research methods were used in the study.

\subsection{Research Group}

The study was conducted with a total of 43 students consisting of an experimental group of 22 and a control group of 21 students studying at the Department of Science Education for Elementary Schools at a State University Faculty of Education in the fall term of 2014-15 academic years. Profile information about the research group is given in Table 1.

Table 1. Profile information about the research groups

\begin{tabular}{|c|c|c|c|c|c|}
\hline & & \multicolumn{2}{|c|}{ Experimental } & \multicolumn{2}{|c|}{ Control } \\
\hline & & $\%$ & $\mathrm{f}$ & $\%$ & $\mathrm{f}$ \\
\hline \multirow[t]{2}{*}{ Gender } & Male & 13.6 & 3 & 23.8 & 5 \\
\hline & Female & 86.4 & 19 & 76.2 & 16 \\
\hline Grade Point & 0.00-0.99 & 0 & 0 & 0 & 0 \\
\hline \multirow[t]{3}{*}{ Average } & $1.00-1.99$ & 31.8 & 7 & 14.3 & 3 \\
\hline & $2.00-2.99$ & 59.1 & 13 & 76.2 & 16 \\
\hline & $3.00-4.00$ & 9.1 & 2 & 9.5 & 2 \\
\hline High School & Regular High & 90.9 & 20 & 66.7 & 14 \\
\hline \multirow[t]{3}{*}{ Graduated } & School & & & & \\
\hline & Anatolian High & 9.1 & 2 & 33.3 & 7 \\
\hline & School & & & & \\
\hline
\end{tabular}

When the relevant literature is examined it is seen that there are many external factors affecting critical thinking dispositions. Therefore, it is important to take these factors under control in studies conducted. In this study, gender, grade point average and the high school students graduated from were taken into consideration and participant profiles were explained in regard to these variables. Within this context, $86,4 \%$ of the participants were female, $14,6 \%$ were male, and while 9,1\%were Anatolian high school graduates, 90,9\%were regular high school graduates. In addition, it is observed that $9,1 \%$ of the participants' grade point averages were between $3.00-4.00,31.8 \%$ were between $1.00-1.99$ and $59,1 \%$ were between $2.00-2.99$. This data is only used to give information about the participants and is not used in other parts of the study. 


\subsection{Data Collection Tools}

\subsubsection{Quantitative Data Collection Tool}

In this study, it was used California Critical Thinking Disposition Inventory (CCTDI) in order to collect quantitative data. This inventory was developed in 1990 after the Delphi project organized by the American Philosophy Association. The inventory is designed to measure the Disposition to think critically, not critically thinking. Facione, Facione, and Giancarlo (1998) reported that the California Critical Thinking Disposition Inventory had a theoretical base, so that when different cultures were concerned, both factor structure and individual items could differ. However, this does not cause any problems in practice since the critical thinking disposition is calculated as total score. In this context, there are a total of 7 subscales of the original scale. The total scores of these 7 subscales are considered to determine the disposition to think critically (Facione, Facione \& Giancarlo, 1998). These sub-scales consist of; a 12-items Truth-Seeking subscale, a 12-items Open Mindedness subscale, a 11-items Analyticity subscale, a 11-items Systematicity subscale, a 10-items Self-Confidences subscale, a 10-items Inquisitiveness subscale and a 10-items Maturity subscale. California Critical Thinking Disposition Inventory, which consisted of 7 dimensions and 75 items, has and internal consistency coefficients (alpha) ranged from .60 to .78 for the subscales and for the whole scale internal consistency coefficient was .90 (Yim, Lee, Chau, Wootton \&Change, 2000). However, Kökdemir (2003) adopted only 6 factors and 51 items of the inventory to Turkish. Adaptation study of the inventory was carried out on 913 students at Başkent University Faculty of Economics and Administrative Sciences who were between 17-28 years of age. When the CCTDI scale reduced to 51 items as a result of the adaptation study of Kökdemir (2003) factors forming the scale and the items under these factors, the resulting factor structure is not different from the original scale according to Kökdemir (2003). However, it has been observed that some items have shifted among factors and that two factors (Open Mindedness and Maturity) have been combined. subscales are " Truth-Seeking ", "Open-Mindedness", "Analyticity", "Systematicity", "self-confidence" and "inquisitiveness". The analytical subscale, which indicates the tendency to use reasoning and objective evidence in the face of potentially problematic situations and difficult problems, has a total of 10 items $(02,03,12,13,16,17,26,37,40)$. The internal consistency coefficient is .75 . The basic logic in open-mindedness is that when an individual makes a decision, he not only looks at his or her own thoughts, but also the views and thoughts of others. This subscale consists of 12 items $(05,07,15$, $18,22,33,36,41,43,45,47,50)$ and the internal consistency coefficient is .75. Inquisitiveness reflects the tendency of a person to learn and learn new things without expecting any gain or interest. The Inquisitiveness subscale consists of nine items $(01,08,30,31,32,34,38,42,46)$ and the internal consistency coefficient is .78. The Self-Confidence subscale reflects the confidence of the subject in his own reasoning process. The internal consistency of the self-confidence subscale, consisting of a total of seven items $(14,29,35,39,44,48,51)$ is .77 . Truth-seeking measures the tendency to evaluate alternatives or disparate thoughts. A total of seven items $(06,11,20,25,27,28,49)$ measure the Truth-seeking sub-dimension. The internal consistency of the scale is .61. The Systematicity subscale is an organized, planned, careful research trend. The internal consistency coefficient of this subscale, consisting of a total of six items $(04,09,10,19,21,23)$ is .63. The internal consistency coefficient (alpha) of whole scale is .88.

The CCTDI translated into Turkish is a six-item Likert type measure. In the evaluation of the items: 1 point given for the phrase "I do not agree", 2 points given for the phrase "I do not agree", 3 points given for the phrase "Partially disagree", 4 points given for the phrase "Partially agree", 5 points given for the phrase "I agree" and 6 points given for the statement "I agree completely". The score range for scale is 51-306. Low scores indicate a very low tendency to think critically and high scores indicate a high tendency to think critically. The items $05,06,09,11,15,18,19,20,21$, $22,23,25,27,28,33,36,41,43,45,47,49$ are scored by reversely.

Subscales of the scale were not used for this study. However, in order to better understand the scale, both for the original scale and the scale translated into Turkish, the newly formed factors and the internal consistency coefficients of the subscales of the items under these factors are included.

A pilot study was conducted to test the reliability of the California Critical Thinking Disposition Inventory before it was used in this study. For the reliability study, the survey was applied to a total of 152 students attending education faculties in mathematics and science education at a state university in the fall semester of the academic year 2014-15. The Cronbach Alpha coefficient was found to be .79 in order to check the internal consistency of the test.

Below is a sample of several items on the scale

1. Considering all the alternatives is a luxury I can't afford.

2. Studying new things all my life would be wonderful.

3. The best argument for an idea is how you feel about it at the moment.

4. My trouble is that I'm easily distracted.

5. It's never easy to decide between competing points of view 


\subsubsection{Qualitative Data Collection Tool}

An open-ended interview questions form was used to define science teacher candidates' opinions about the method applied in the course. There were three open-ended questions in the interview form. These questions are as follows: (1) what are your opinions about the promotion of material development course with the Moodle application? (2) what are your opinions about in-class application of material development course? (3) what are your suggestions for improvement of material development course? Four experts in the field (two of the experts are in the field of measurement and evaluation, and the other two are experts in the field of science education) were consulted about the content validity of the interview form. They were asked to evaluate it as "appropriate", "inappropriate" and "needs improving". Reliability of the assessment instrument was determined by evaluating responses from a total of three experts and by providing consistency among them. One of the experts is science education expert; the other one is educational sciences expert and the last one is the measurement and evaluation expert. Agreement coefficient between the opinions of experts and the researcher defined by Miles and Huberman (1994) is found to be .80 according to the formula [number of agreements /( number of agreements +Disgreements) x100].

\subsection{Data Analysis}

The independent samples t-test and paired samples t-test were used to analyse quantitative data. Open-ended questions in the questionnaire used in the study were analysed with descriptive analysis technique (Bogdan \& Biklen, 1998) and the results were later presented quantitatively. "Sentences" and "words" were taken as evaluation units. Within this context, primarily, sentences/words in questionnaire forms that have a judgement were coded. The steps followed in the analyses of qualitative data are described in Table 2.

Table 2. Overall presentation of the analysis phase of qualitative data

The answers given by the pre service science teachers to the open-ended questions in the questionnaire were analyzed separately by two researchers.

Analyzes of two researchers were compared to determine the reliability of analyzes. In this process, "agreements" and "disagreements" were identified. The following formula was used by Miles and Huberman (1994) for the reliability of the study. $\mathrm{p}=.92$ was considered and the study was considered reliable.

Formula: $\mathrm{p}$ (reability) $=[\mathrm{Na}$ (number of agreements) $/ \mathrm{Na}$ (number of agreements) $+\mathrm{Nd}$ (number of disagreements)] X 100

The data were recorded in tabular form classification.

Findings related to the problem of researching were considered by reference to the answers of the participants

\subsection{Implementation Phase}

The implementation phase continued four hours a week for 12 weeks. Students were given general information about the implementation and pre-tests were administered in the first week. Students' Moodle program registrations were made and information about how to use the Moodle program was given in the second week. The subjects started to be taught theoretically for six weeks starting from the third week. In this part students discussed the next lesson's topic before coming to class on Moodle with online argumentation method in their free time for about a week. The lesson in question was developed and taught according to the mistakes and missing information obtained after argumentation. The lesson was finished when the question of the discussion was summarised by the whole class at the end of the lesson. After the theoretical subjects were finished, students presented the materials they prepared on the learning outcome they had chosen during the last three weeks in class. The same scales were applied again as post-test at the end of the $12^{\text {th }}$ week.

\section{Results}

\subsection{Is There a Statistically Significant Difference Between Pre-test and Post-Test Averages of Experimental and Control} Groups Teacher Candidates 'Critical Thinking Disposition?

Whether there is a statistically significant difference between pre-test and post-test averages of teacher candidates' critical thinking disposition with regard to the groups is analysed with independent groups t-test and the data is presented in Table 3. 
Table 3. Independent T-Test Results of Pre-Test and Post-Test Averages of Experimental and Control Groups Teacher Candidates' Critical Thinking Disposition

\begin{tabular}{|c|c|c|c|c|c|c|c|}
\hline $\begin{array}{l}\text { Critical thinking } \\
\text { disposition scale }\end{array}$ & Group & $\mathrm{N}$ & $X$ & $\mathrm{~S}$ & $\mathrm{df}$ & $\mathrm{T}$ & $\mathrm{p}$ \\
\hline \multirow[t]{2}{*}{ Pre-test } & Experimental & 22 & 4.5 & .29 & 41 & .42 & .675 \\
\hline & Control & 21 & 4.5 & .42 & & & \\
\hline \multirow[t]{2}{*}{ Post-test } & Experimental & 22 & 4.6 & .28 & & 2.69 & .010 \\
\hline & Control & 21 & 4.4 & .31 & 4 & & \\
\hline
\end{tabular}

Independent groups t-test was applied to compare pre-test and post-test points of teacher candidates' critical thinking skills with regard to the experimental and control groups. When the pre-test points were analysed, while no statistically significant difference was identified between the experimental and control groups teacher candidates' points $\left[\mathrm{t}_{(41)}=.42\right.$ $\mathrm{p}>.05]$, a statistically significant difference was identified between their post-test points $\left[\mathrm{t}_{(41)}=2.69 \quad \mathrm{p}<.05\right]$ in favour of the experimental group.

\subsection{Is There a Statistically Significant Difference Between Pre-test Averages and Post-Test Averages of Experimental Group Teacher Candidates' Critical Thinking Disposition}

Whether there is a statistically significant difference between pre-test and post-test averages of experimental group teacher candidates' critical thinking disposition is analysed with independent groups t-test and the data is presented in Table 4.

Table 4. Independent t-Test Results of Pre-Test and Post-Test Points of Experimental Group Critical Thinking Disposition

\begin{tabular}{lllllll}
\hline & $\bar{X}$ & $\mathrm{~N}$ & $\mathrm{~S}$ & $\mathrm{df}$ & $\mathrm{t}$ & $\mathrm{p}$ \\
\hline Pre-test & 4.51 & 22 & .29 & 21 & 2.38 & .02 \\
\hline Post-test & 4.67 & 22 & .28 & & & \\
\hline
\end{tabular}

It is observed that teacher candidates' point average in the pre-test is 4.51 and post-test point average is 4.67 in Table 4 . According to the paired samples t-test applied to understand if there is a statistically significant difference between these points, a statistically significant difference has been found on behalf of post-test points between them $\left[\mathrm{t}_{(21)}=2.38\right.$, $\mathrm{p}<.05]$.

3.3 Is There a Statistically Significant Difference Between Pre-test Averages and Post-Test Averages of Control Group Teacher Candidates' Critical Thinking Disposition?

Whether there is a statistically significant difference between pre-test and post-test averages of control group teacher candidates' critical thinking skills is analysed with independent groups t-test and the data is presented in Table 5 .

Table 5. Independent T-Test Results of Pre-Test and Post-Test Points of Control Group Critical Thinking disposition

\begin{tabular}{lllllll}
\hline & $\bar{X}$ & $\mathrm{~N}$ & $\mathrm{~S}$ & $\mathrm{df}$ & $\mathrm{t}$ & $\mathrm{p}$ \\
\hline Pre-test & 4.56 & 21 & .42 & 20 & 1.02 & .30 \\
\hline Post-test & 4.42 & 21 & .31 & & &
\end{tabular}

It is observed in Table 4that teacher candidates' point average in the pre-test is 4.56 and post-test point average is 4.42 . According to the paired samples t-test applied to understand if there is a statistically significant difference between these points, no statistically significant difference has been found between them $\left[\mathrm{t}_{(20)}=1.02, \mathrm{p}>.05\right]$. 


\subsection{Science Teacher Candidates' Opinions About the Moodle Application Supported Online Argumentation Implementation}

Table 6. Science Teacher Candidates' Opinions about the Moodle Application Supported Online Argumentation Application

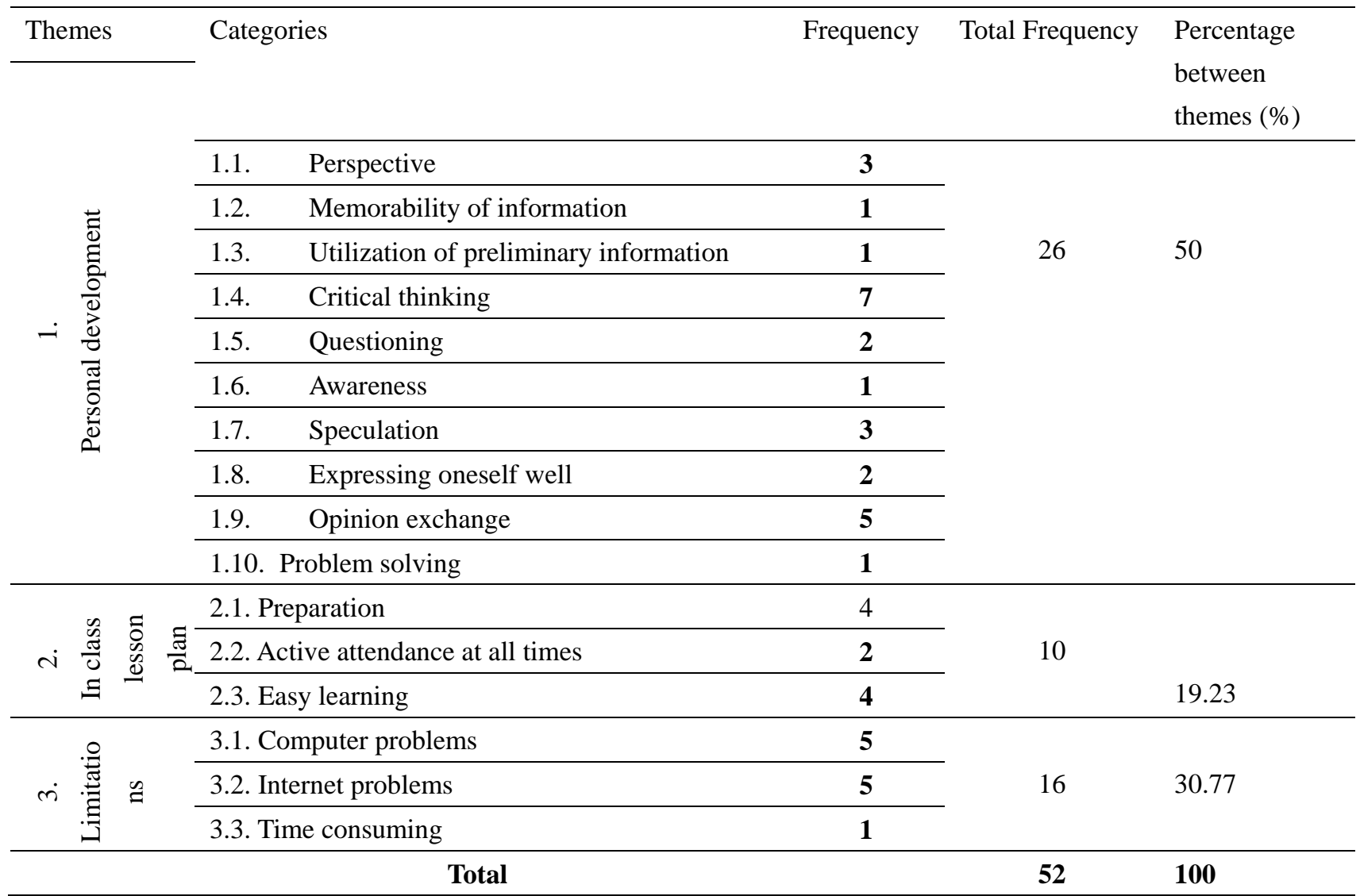

When teacher candidates' opinions about the Moodle application supported online argumentation implementation are examined it is identified that the implementation supports the improvement of teacher candidates' critical thinking skills the most according to Table 5. Regarding the issue, S9 tells: "It is good that we have a discussion about the issue before we come to the school. We offer different views. This allows us to look at our issues in a different way. Apart from this factor it is observed that, teacher candidates express they exchange opinions more easily, can prepare for the lesson more effectively and utilise their preliminary knowledge with the application. S18, also commented on the issue: "Our pre-class debate provides both an opportunity to prepare for class and an environment to defend our ideas. We also read from our friends' opinions, what in our views are different, what we cannot see, or what our friends are defending differently from us. S11 says," During the discussions, I read how my other friends defend their ideas. The information they use can be influential in changing my ideas. Sometimes my ideas are stronger because of the information I use. I can also impress my friends. The debate we have made prior to class is useful for learning easily. In the limitations part of the application, it is identified that teacher candidates have computer and Internet access problems especially out of the university and therefore not all the teacher candidates can always follow the Moodle application, as they want. Regarding the issue s4 said: "I want to participate in the discussion process. However, I do not have internet at home. There is no environment in the school for internet access. I have to constantly go to internet cafes for this application. This puts me in a very difficult situation. "Also S8 states; "I do not have computer and internet at home, so I cannot participate in the discussion. Since I do not know what was discussed, I often do not understand what happens in classroom."

\section{Discussion}

Critical thinking is one of the over emphasized trends in today's education system and it is an actively used skill in investigating-questioning process. As the general purpose of science education is to try and understand the events in nature, investigating-questioning process is also fundamental to science education. Students try to understand the events and phenomena by applying experimental procedures and try to make sense of the information in their own cognitive processes. Thus, dispositions used in this process do not effectively improve in the family and social 
environment (Schafersman, 1991). It is necessary that dispositions with complex structures like critical thinking are addressed carefully in the formal education system. For this, however, primarily teachers should have these dispositions. Therefore, improvement of critical thinking disposition should be specially given importance at faculties of education, and it is important to create essential settings in these departments. The purpose of this study is to investigate the effects of teaching technologies and material development course taught through Moodle based online argumentation application on critical thinking abilities of third year (junior) science teacher candidates. At the end of the research, while a statistically significant difference in critical thinking dispositions of teacher candidates is observed in favour of post-test results of the experimental group, no statistically significant difference is observed in the control group. In other words, according to the results of the research, Moodle-supported online argumentation has been a positive influence on the disposition of critical thinking. It can be said that this situation arises from both the general structure of argumentation practices and the support of Moodle application.

Argumentation implementation is a learning approach in which data obtained experimentally or from various sources are reasoned, evaluated, and reasons opposing and supporting the data are argued generally in a social interaction environment (Munekke, Amelsvoort \& Andriessen, 2003). With this application, students ask questions, assert arguments and by supporting these arguments structure the information in an investigating-questioning based learning environment (Günel, Kıngır \& Geban, 2012). This process supports the improvement of their critical thinking disposition. When the relevant literature is examined it is observed that a large number of studies express argumentation applications support development of critical thinking disposition (Lawson, 2003; Yeşiloğlu, 2007). In addition, the argumentation practices were supported by the Moodle program. This program has provided an educational environment to students in which they can behave freely, as well as they can share and comment on course materials. This may have supported their development of critical thinking dispositions. When the opinions of the candidate teachers regarding the applied method are examined, it is seen that the opinions are parallel to this interpretation. Candidate teachers stated that they started to evaluate the preliminary information about the events with this application and therefore their points of view changed. They also emphasized that their inquiry skills developed because they were involved in exchanging ideas, which in turn supported their ability to express themselves. Moreover, when the teacher candidates' opinions about the subject were investigated it was found that the teacher candidates strongly supported the elimination of internet connection problems to improve the course. With online argumentation implementation, students discussed on a question about the subject for a week before coming to class and then came to class with questions that arose in their minds during that discussion. These questions were tried to be answered in the lessons done in class. However, students need internet connection to continuously follow the discussion. Students who do not have internet access cannot get involved and are left out of this process. Therefore, in order to employ these applications, the school setting must absolutely be supportive of the application and answer students' needs.

\section{References}

Bailin, S. (2002). Critical thinking and science education. Science \& Education, 11, 361-375. https://doi.org/10.1023/A:1016042608621

Bruner, J. (1966). Toward a theory of instruction. Cambridge, MA: Harvard University Press

Choi, A., Hand, B., \& Norton-Meier, L. (2014). Grade 5 students' online argumentation about their in-class inquiry investigations. Research in Science Education, 44(2), 267-287. https://doi.org/10.1007/s11165-013- 9384-8

Facione, P. A., Facione, N. C., \& Giancarlo, C. A. (1998). The california critical thinking disposition inventory test manual (revised). Millbrae, CA: California Academic Press

Fettahlıoglu, P. (2012). The usage of argumentation-based and problem-based learning approaches intended for developing the environmental literacy of pre-service science teachers. Unpublished doctoral thesis. Gazi University, Ankara, Turkey.

Foundation for Critical Thinking (FCT). (1992). Critical thinking: Basic questions and answers. Retrieved November 15, 2012 from http://www.criticalthinking.org/pages/critical-thinking-basic-questions- amp-answers/409

Günel, M., Kıngır, S., \& Geban, Ö. (2012). Analysis of argumentation and questioning patterns in argumentbased inquiry classrooms. Education and Science, 37(164), 316-330.

İpşiroğlu, Z. (2002). Düşünme korkusu. İstanbul: Papirüs Yayınevi

Jimenez, A. M. P. (2008) Designing argümantation learning environments. In: S. Erduran and M.P. Jimenez Alexandre (eds.) Argumantation in science education: perspectives from classroom based research (p. 91-115). Dordrecth: Springer.

Jimenez, A. M. P., \& Puig, B. (2011). The role of justification in integrating evidence in arguments: making sense of 
gene expression. Paper presented in the Esera Meeting, LYON.

Kaleci, D. (2013). A new C compiler developed extension for Moodle. International Journal of Human Sciences, 10(Special Issue), 27-34.

Kaleci, D., \& Kapıdere, M. (2014). Design of web-based score package for Moodle: sample of preparing question and exam. Journal of Instructional Technologies \& Teacher Education, 3(2), 29-39.

Kelly, G., \& Takao, A. (2002). Epistemic levels in argument: An analysis of university oceanography students' use of evidence in writing. Science Education, 86(3), 314-342. https://doi.org/10.1002/sce.10024

Kökdemir, D. (2003). Decision making and problem solving under uncertainty. Unpublished Doctoral Thesis, Ankara University, Ankara, Turkey.

Lawson, A. E. (2003). The nature and development of hypothetico-predictive argumentation with implications for science teaching. International Journal of Science Education, 25(11), 1387-1408. https://doi.org/10.1080/0950069032000052117

McMillan, J. H., \&Schumacher, S. (2006). Research in education: Evidence-based inquiry (Sixth Edition). London: Pearson.

Miles, M. B., \& Huberman, A. M. (1994). Qualitative Data Analysis (2nd edition). Thousand Oaks, CA: Sage Publications.

Moodle. (2017a). Moodle Statistics. Retrieved November 15, 2017 from https://Moodle.net/stats/?lang=tr

Moodle. (2017b). Open Source Learing Platform. Retrieved November 15, 2017 from https://docs.Moodle.org/31/en/About_Moodle

Munekke, E. L., Amelsvoort, M. A. A., \& Andriessen, J. E. B. (2003). The role of diagrams in collabrortaive argumentation based learning. International Journal of Educational Research, 39, 113-131. https://doi.org/10.1016/S0883-0355(03)00076-4

Paul, W. R. (1993) Critical thinking: How to prepare students for a rapidly changing world. Santa Rosa, CA: Foundation for Critical Thinking.

Piwek, P., \& Keynes, M. (2013). Supporting Computing and Technology distance learning students with developing argumentation skills. Paper presented at the 2013 IEEE Global Engineering Education Conference (EDUCON), Technische Universität Berlin, Berlin, Germany. https://doi.org/10.1109/EduCon.2013.6530115

Rafi, A., Samsudin, K., \& Hanafi, H. F. (2015). Differences in Perceived Benefit, Use, and Learner Satisfaction between Open Source LMS and Proprietary LMS. https://doi.org/10.5772/60670

Ryan-Atkin, H. (2015). The use of an on-line discussion forum to support collaborative studying practices and argumentation amongst trainee teachers. Teacher Education Advancement Network Journal, 7(1), 25 - 37.

Sandoval, W. A. (2003). Conceptual and epistemic aspects of students' scientific explanations. Journal of the Learning Sciences, 12(1), 5-51. https://doi.org/10.1207/S15327809JLS1201_2

Schafersman, S. D. (1991). An Introduction to Critical Thinking. 11.03.2012 retrived from http://smartcollegeplanning.org

Schoonenboom, J. (2014). Using an adapted, task-level technology acceptance model to explain why instructors in higher education intend to use some learning management system tools more than others. Computers \& Education, 71, 247-256. https://doi.org/10.1016/j.compedu.2013.09.016

Smith, G. F. (2003). Beyond critical thinking and decision making: teaching business students how to think. Journal of Management Education, 27, 24. https://doi.org/10.1177/1052562902239247

Sözer, E. (1991). Türk Üniversitelerinde Öğretmen Yetiştirme Sistemlerinin Öğretmenlik Davranışları Kazandırma Yönünden Etkililiği. Eskişehir: Anadolu Üniversitesi Basımevi.

Thomas, I. (2009). Critical thinking, transformative learning, sustainable education, and problem-based learning in universities. Journal of TransformativeEducation, 7, 245. https://doi.org/10.1177/1541344610385753

Toulmin, S. (1958). The uses of argument. Cambridge: Cambridge University Press.

Tümkaya, S., \& Aybek, B. (2008). Üniversite öğrencilerinin eleştirel düşünme eğilimlerinin sosyo-demografik özellikler açısından incelenmesi. Çukurova Üniversitesi, Sosyal Bilimler Enstitüsü, 2(17), 13-24.

Yeşiloğlu, S. N. (2007). Teaching gases topic to high school students trough argumentation. Unpublished Graduate Thesis, Gazi University, Ankara, Turkey. 
Yim,W., Lee, D. T. F., Lee, I. F. K., Chau, J. P. C., Wootton, Y. S. Y., \& Chang, A. M. (2000). Disposition Towards Critical Thinking: a Study of Chinese Undergraduate Nursing Students. Journal of Advanced Nursing, 32(1), 84-90. https://doi.org/10.1046/j.1365-2648.2000.01417.x

Zengin, F. K., Keçeci, G., \& Kırılmazkaya, G. (2012). Elementary school studentslearning about nuclear power plants with the on-line scientific argumentation learning program. e-Journal of New World Sciences Academy NWSA-Education Sciences, 7(2), 647-654.

Zohar, A., \& Nemet, F. (2002). Fostering students' knowledge and argumentation skills through dilemmas in human genetics. Journal of Research in Science Teaching, 39(1), 35-62. https://doi.org/10.1002/tea.10008

\section{Copyrights}

Copyright for this article is retained by the author(s), with first publication rights granted to the journal.

This is an open-access article distributed under the terms and conditions of the Creative Commons Attribution license which permits unrestricted use, distribution, and reproduction in any medium, provided the original work is properly cited. 